\title{
Belonging, Togetherness and Food Rituals
}

\author{
Ami Rokach \\ York University, Toronto, Canada
}

Email: arokach@yorku.ca

How to cite this paper: Rokach, A. (2020). Belonging, Togetherness and Food Rituals. Open Journal of Depression, 9, 77-85. https://doi.org/10.4236/ojd.2020.94007

Received: October 14, 2020

Accepted: November 17, 2020

Published: November 20, 2020

Copyright $\odot 2020$ by author(s) and Scientific Research Publishing Inc. This work is licensed under the Creative Commons Attribution International License (CC BY 4.0).

http://creativecommons.org/licenses/by/4.0/

\begin{abstract}
In this article I highlighted the importance of belonging, togetherness, and interpersonal support, and examined eating rituals, in various cultures and religions, that emphasize that food is not just for the body, but can nurture the soul and bond people.
\end{abstract}

\section{Keywords}

Loneliness, Belonging, Social Support, Food, Rituals, Religion, Culture

"Humans are obligatorily gregarious ... The average person spends nearly $80 \%$ of waking hours in the company of others ... and their survival depends on their collective abilities, rather than on their individual might" (Distel et al., 2010: p. 480-481).

\section{Belonging}

Belonging, being part of the larger community and having a special someone who cares deeply about us, is an essential need for humans who have been referred to as social animals (Rokach, 2017). Devoldre, Davis, Verhofstadt, \& Buysse pointed out the importance of social support by indicating that the stresses and negative effects on mental and physical health that lack of such support may bring about, are varied and potentially serious (See also Rook \& Charles, 2017). As Gordon (1976) so poignantly observed, "To be alone is to be different, to be different is to be alone, and to be in the interior of this fatal circle is to be lonely. To be lonely is to have failed" (p. 15). We seem to be living in a "Noah's Ark" society where everything goes by two, and if you are lonely, you are out of place, and seen as a failure with whom no one may want to associate.

Baumeister \& Leary (1995) suggested that humans have a pervasive drive to form and keep lasting significant and positive relationships. However, they added, failure to have those belongingness needs met, would quite certainly lead 
to feelings of social isolation and loneliness. When addressing belonging, the literature indicates that it is not the quantity but the quality of relationships that matter and which plays a significant role in creating a nurturing and inclusive relationship while Facebook "friends" could never do that (see Rokach, 2014). Cacioppo, Reis, \& Zautra (2011) observed that "human evolutionary heritage has endowed us with the capacity to feel the pain of social isolation and the rewards of social connection. Importantly, it has also endowed us with the capacity to feel others' pain and the compassion to care for the sick and the elderly far beyond their reproductive or instrumental utility" (p. 43). Weil (1997), a holistic physician, noted that humans are highly social, communal animals that are meant to live in families, tribes and communities, and when they lack those connections they suffer, as was evidence by many during the COVID-19 pandemic and lockdown. The practice of ex-communication that was the Church's most severe social reprimand and the solitary confinement used in jails to punish unruly criminals are both indicative of how painful it is to be isolated from other humans (Leary \& Springer, 2001).

Ornish (2007), hailing the power of connection and belonging, observed that "medicine today focuses primarily on drugs and surgery, genes and germs, microbes and molecules. Yet love and intimacy are at the root of what makes us sick and what makes us well. If a new medication had the same impact, failure to prescribe it would be malpractice" (p. 30). Rook \& Charles (2017) highlighted the importance of belonging by stating that having close social ties has not been seen to be an important health behavior. Yet carefully controlled epidemiological studies found that health is significantly affected by close social connections and lack, thereof have an effect comparable to or greater than that of such well-established risk factors as smoking, alcohol consumption, obesity, and physical inactivity. It was repeatedly documented that being socially integrated and having access to social support are associated with improved physical health, including reduced risks for infectious illness, cardiovascular disease and overall cognitive and physical decline.

\section{Culture, Belonging and Food Rituals}

Research points out that culture plays an important role in relationships (Campos \& Kim, 2017). Culture, thus, influences how individuals create, maintain and terminate their relationships with family members, friends and intimate partners (Hofstede, Hofstede, \& Minkov, 1997; Mojaverian, \& Kim, 2013). Campos \& Kim (2017) indicated that there is, at present, relatively little empirical research that examined social interactions and relationships in other cultures, though there are some published reports on some European cultures.

Eating is not just consuming food or fluids. Eating, especially, with one's loved ones is a ritual. Rook (1985) defined a ritual as "a type of expressive, symbolic activity constructed of multiple behaviors that occur in a fixed, episodic sequence, and that tends to be repeated over time" (p. 252). While rituals may oc- 
cur for one person, they are much more influential when they occur with a family or friends. Such a ritual may include the kind of food that is consumed [i.e. on holidays where there is a typical food that is served], where it is performed, the various factors that may be added to the food such as prayers, stories, or being together and connecting before and after food is consumed. It seems, suggested Rook (1985), that the rituals related to food may tell us quite a bit about social constructs, rites of passage, and various manners of behavior and interaction.

Food and drink are fuel for our bodies, but actually represent more than just that. Food may indicate belonging, being part of a larger group and celebration or alternatively condolence. Food is deeply influenced by culture, history, sociology and even psychology. Watching how people eat, even more than what they eat, could teach us a lot about the family or organizational system and the prevailing culture. This day and age, we can eat in restaurants, at home, grab a quick bite without even sitting down, or attend an elaborate meal. These are all telltales not about the food, but about those who consume it.

The oldest ritual on earth involves families and groups of people eating together. Visser (1991) observed that the custom goes back two million years, when the hunters would return at the end of the day to divide up food with their family or friends. He further observed that the process of collection, preparation and division of food, may have encouraged the development of kinship systems, such as who eats with whom, the language which was used to discuss food and how to secure it, and for planning the next day's meal. It has been the process that helped bring people together and helped define their groups, rituals and history.

Let's examine food rituals and behaviors in various regions of the world. The nomadic Bedouin culture in the Middle East has influenced its tendency towards hospitality that may not be found in other regions. Travelers seeking relief from the harsh desert conditions, would be invited into their homes, and be fed and helped with what they need. That has been a central feature of the Middle Eastern culture and cuisine and seems to counteract the hostility that exists between the countries that are situated in that region (LaRock, 2018).

The Jews all over the world, celebrate Passover with the Seder [meaning order', since the food which is consumed during that evening is served in a specific order], and that is a main ritualistic food and family coming together to celebrate the holiday, as it has been done for thousands of years virtually unchanged. During the Seder, the Haggadah which means "the telling" is the book used at the Passover Seder, where the Jews' exodus from slavery in Egypt is recounted with songs, prayers, and stories (Dash, 2016). The Matzoh, which is a staple of the Passover celebration, is a cracker-like flour and water bland crisp eaten instead of bread for the eight days of Passover-a ritual when it is prepared in a specific manner, and a ritual when it is eaten (Fulton, 2016).

In Catholicism the story of Jesus Christ's life and death is told through food and drink in the ritual of the Eucharist, performed at every Catholic mass. A 
communion wafer and wine shared by each member honors Jesus body and blood. The wafer, the "Eucharist" is blessed by the priest and represents Christ's body which he sacrificed for our sins, while the wine represents his blood. The ritual is rooted in Christ's Last Supper which he shared with his apostles before being sentenced to death (O'Donoghue, 2012).

Bengalis, in South Asia, take food to another level in their haldi, their traditional wedding ceremony. While the bride and groom's families carry presents for one another, the bodies of the couple who is about to get married, get "painted" with a turmeric paste, and a pair of fish dressed as the couple is introduced as a measure of good luck, an activity which encourages cooperation, good humor, and familial interactions (Amarujala, 2018).

The Oplatek, or Polish Christmas wafer, tells a story to Poles and Americans of Polish descent. Sitting around the Christmas table, the most senior member tastes the Oplatek and then offers it to his or her spouse, or to the next most senior member of the household. The ritual involves extending good wishes for good health, happiness, professional or academic success, etc. The receiver of the wafer breaks and eats a piece and returns the good wishes, before passing it to the next in line. The ritual is performed with solemnity and warmth by all present which may come out feeling that they are an integral part of the family and adhere to the groups' norms and behaviors (Anderson, 2013).

The Japanese experience of the self, centers contrary to modern psychology, on one's interdependence on the community, on engagement and harmony with others, and on open-hearted and sensitive cooperation (Markus \& Kitayama, 1991). Dependency, cooperation, empathy, reciprocity and belongingness indicate successful development in the Japanese culture. Consequently, while the Western approach regards the failure to separate as a developmental setback, in Japan, a failure to connect is cause for concern (Friedman, 2007).

In Chinese and Japanese societies, people use meals to connect with others, enhance established relationships, or create new ones. Different food, in this culture, seem to convey different meanings to those gathered around the table, with the more expensive foods indicating wealth as well as respect for guests. Interestingly, compared to the Western countries, Chinese spend appreciably more time cooking and it can get to as long as two to three hours spent in the kitchen daily.

Campos \& Kim (2017) examined, in their review of cultural influences on relational behaviors, the collectivistic East Asian and Latino cultures which are characterized by low relational mobility and relationships which are based on interdependence with close others. There is, they pointed out, "harmony collectivism" in the East Asian culture which highlights for people the "price" of remaining out of the group. East Asian are more negatively impacted by interpersonal conflicts than do Europeans or Americans (Hashimoto, Mojaverian, \& Kim, 2012). Consequently, East Asians navigate their relationships cautiously in order to avoid the negative consequences (Butler, Lee, \& Gross, 2009; Tsai, 
Knutson, \& Fung, 2006). Relationship closeness is, unlike in North America, communicated by practical advice rather than direct expression of, say, love or fondness (Chen, Kim, Mojaverian, \& Morling, 2012).

Meals, in East Asian countries are seen as a communal event, aiming for all dishes on the table to be shared, and the round tables which are used in order to enhance each person's ability to easily get the dish he or she wants. Sitting arrangements, such as who sits first and other customs and etiquette surround the consumption of the meal (Ma, 2015). On the contrary, in refugee camps in Syria or Jordan, meals are not shared on holidays. The refugees see meals as their way to hold on to their heritage and traditions, while the couple cooks together, thus utilizing their union to enhance the customs that they brought from "back home".

In Latino contexts, a blend of collectivism that is termed convivial collectivism is found. Here, interdependent relationships are built and maintained by open and frequent display of positive emotions, social gathering on a regular basis, and behaviors that honor the dignity of self and others (Campos \& Kim, 2017). Thus, simpatía, respeto, and familism are the central in relationship in the Latino culture. Simpatia is the emphasis on creating positive emotional tone and avoiding negativity as a precursor to an enjoyable social interaction. Respeto is the formal politeness which is practiced in order to usher in a smooth and as much as possible conflict free pleasant social interaction, and Familism is the emphasis placed on the closeness, support, and emotionally positive familial relations (Campos, Ullman, Aguilera, \& Dunkel Schetter, 2014; Holloway, Waldrip, \& Ickes, 2009).

Food is even present in death related rituals. In Mexico they observe the Day of the Dead, where it is believed that the border between the spirit and the real world dissolves. It is celebrated throughout the country with decorated skulls made of sugar, celebrating the Aztec goddess of the underworld. The Mexicans believe that during that day the dead awaken and briefly return to our world to feast, dance and drink with their loved ones. The living family members, meantime, treat the deceased as guests of honor and leave the dead person's favorite foods and offerings at gravesites or on the ofredas built in their dwellings (History.com, 2018). Food can, indeed, be quite central and comforting in difficult times (Visser, 1991).

The North American culture is based on European Protestant origins and commonly amounts to an individualistic context coupled with relatively high relational mobility, where individuals have the choice to voluntarily form and terminate relationships (Campos \& Kim, 2017; Schug, Yuki, \& Maddux, 2010). Consequently, today's meals are commonly less a sit-down event, and more like a moving meal, with such distractions as TV, cell phones, or fast food being delivered. However, it needs to be pointed out that this is not how it began and many struggles to let go of the tradition of coming together at the end of the day to "break bread" together. Many Europeans immigrated to America in the 1800 s 
and 1900s, and brought with them the evening supper tradition, consumed on the dining table which they also imported from their own cultures. Up to the latter part of the $20^{\text {th }}$ century, everyday dinner was consumed by the whole family at home. The shared meal was a time when the family gathered together and exchanged stories of their whereabouts during the day. Even coffee was a symbol of celebration and class in the 1930s, very unlike Starbucks' coffee that we hurriedly gulp today (Anderson, 2016).

\section{Conclusion}

To conclude, our human history is heavily influenced by the ritual of food and its incredible place in our human experiences, connection and belonging. Food is, thus, a symbol of life, of belonging, and of a community rooted in long standing traditions (Humphrey \& Humphrey, 1988). Visser (1991) observed in that respect, that "we still remember that breaking bread and sharing it with friends means friendship itself, and also trust, pleasure, and gratitude in the sharing ... food in general, becomes, in its sharing, the actual bond which unites us" (p. 3). It is noted that the 21 st century, is the age of relationships. We believe in the importance, uniqueness, and availability of methods of relating to others. At present, relationships appear to be the main avenue, and perhaps the only means, by which self-esteem can truly be affirmed. Our social environment influences health and wellbeing (Begen \& Turner-Cobb, 2015). And so are the evolutionary and practical benefits of inclusion in the naturalistic environment (Leary, 2010). Research evidence suggests that inclusion and belonging increase trust (Hillebrant, Sebastian, \& Blakemore, 2011) and reduce the impact of prior exclusion, if there was one (DeWall et al., 2010) with consequent health benefits. The recent Corona virus pandemic provided a real-life example of how people get very stressed when they cannot freely connect with their fellow man. Belonging and social connection are not only beneficial during times of stress but also play an important role during non-stressful times, by encouraging people's wellbeing, and fostering cohesion of families and communities (Feeney \& Collins, 2015; Lakey \& Orehek, 2011). Moreover, those who feel supported and part of a caring social network are able to celebrate positive life events, increasing health promoting effects of positive emotions, and enhance personal strengths that are cultivated during good times (Gable \& Reis, 2010; Pressman et al., 2009).

\section{Conflicts of Interest}

The author declares no conflicts of interest regarding the publication of this paper.

\section{References}

Amarujala, E. (2018). Significance and Importance of Fish in Bengali Weddings. Mangal Parinay.

https://www.mangalparinay.com/blog/wedding-traditions-rituals/significance-and-imp ortance-of-fish-in-bengali-weddings 
Anderson, C. (2013). In Search of the Origins of the Oplatek. The Polish Review, 58, 65-76. https://doi.org/10.5406/polishreview.58.3.0065

Anderson, R. (2016). A Seat at the Bar: Issues of the Race and Class in the World of Specialty Coffee.

https://savageminds.org/2016/08/21/a-seat-at-the-bar-issues-of-race-and-class-in-theworld-of-specialty-coffee

Baumeister, R. F., \& Leary, M. R. (1995). The Need to Belong: Desire for Interpersonal Attachments as a Fundamental Human Motivation. Psychological Bulletin, 117, 497-529. https://doi.org/10.1037/0033-2909.117.3.497

Begen, F. M., \& Turner-Cobb, J. M. (2015). Benefits of Belonging: Experimental Manipulation of Social Inclusion to Enhance Psychological and Physiological Health Parameters. Psychology \& Health, 30, 568-582. https://doi.org/10.1080/08870446.2014.991734

Butler, E. A., Lee, T. L., \& Gross, J. J. (2009). Does Expressing Your Emotions Raise or Lower Your Blood Pressure? The Answer Depends on Cultural Context. Journal of Cross-Cultural Psychology, 40, 510-517. https://doi.org/10.1177/0022022109332845

Cacioppo, J. T., Reis, H. T., \& Zautra, A. J. (2011). The Value of Social Fitness with an Application to the Military. American Psychologist, 66, 43-51.

https://doi.org/10.1037/a0021419

Campos, B., \& Kim, H. S. (2017). Incorporating the Cultural Diversity of Family and Close Relationships into the Study of Health. American Psychologist, 72, 543-554. https://doi.org/10.1037/amp0000122

Campos, B., Ullman, J. B., Aguilera, A., \& Dunkel Schetter, C. (2014). Familism and Psychological Health: The Intervening Role of Closeness and Social Support. Cultural Diversity and Ethnic Minority Psychology, 20, 191-201. https://doi.org/10.1037/a0034094

Chen, J. M., Kim, H. S., Mojaverian, T., \& Morling, B. (2012). Culture and Social Support Provision: Who Gives What and Why. Personality and Social Psychology Bulletin, 38, 3-13. https://doi.org/10.1177/0146167211427309

Dash, M. (2016). What Is a Seder? https://www.haggadot.com/clip/what-seder-12

DeWall, C., MacDonald, G., Webster, G. D., Masten, C. L., Baumeister, R. F., Powell, C., Eisenberger, N. I. et al. (2010). Acetaminophen Reduces Social Pain: Behavioral and Neural Evidence. Psychological Science, 21, 931-937. https://doi.org/10.1177/0956797610374741

Distel, M. A., Rebollo-Mesa, I., Abdellaoui, A., Derom, C. A., Willemsen, G., Cacioppo, J. T., \& Boomsma, D. I. (2010). Familial Resemblance for Loneliness. Behavioural Genetics, 40, 480-494. https://doi.org/10.1007/s10519-010-9341-5

Feeney, B. C., \& Collins, N. L. (2015). A New Look at Social Support: A Theoretical Perspective on Thriving through Relationships. Personality and Social Psychology Review, 19, 113-147. https://doi.org/10.1177/1088868314544222

Friedman, R. L. (2007). Widening the Therapeutic Lens: Sense of Belonging as an Integral Dimension of the Human Experience. A Dissertation Submitted to the Wright Institute Graduate School.

Fulton, A. (2016). The Crummy History of Matzoh. National Geographic Online. http://www.com/people-and-culture/food/the-plate/2016/04/22/the-crummy-history-o f-matzoh

Gable, S. L., \& Reis, H. T. (2010). Good News! Capitalizing on Positive Events in an Interpersonal Context. In M. P. Zanna (Ed.), Advances in Experimental Social Psychology (Vol. 42, pp. 195-257). San Diego, CA: Academic Press.

https://doi.org/10.1016/S0065-2601(10)42004-3 
Gordon, S. (1976). Lonely in America. New York: Simon \& Schuster.

Hashimoto, T., Mojaverian, T., \& Kim, H. S. (2012). Culture, Interpersonal Stress, and Psychological Distress. Journal of Cross-Cultural Psychology, 43, 527-532. https://doi.org/10.1177/0022022112438396

Hillebrant, H., Sebastian, C., \& Blakemore, S. J. (2011). Experimentally Induced Social Inclusion Influences Behavior on Trust Games. Cognitive Neuroscience, 2, 27-33. https://doi.org/10.1080/17588928.2010.515020

History.com (2018). Day of the Dead. https://www.history.com/topics/haloween/day-of-the-dead

Hofstede, G., Hofstede, G. J., \& Minkov, M. (1997). Cultures and Organizations. New York: McGraw-Hill.

Holloway, R. A., Waldrip, A. M., \& Ickes, W. (2009). Evidence That a Simpático Self-Schema Accounts for Differences in the Self-Concepts and Social Behavior of Latinos versus Whites (and Blacks). Journal of Personality and Social Psychology, 96, 1012-1028. https://doi.org/10.1037/a0013883

Humphrey, T. C., \& Humphrey, L. T. (1988). We Gather Together: Food and Festival in American Life. Ann Arbor, MI: UMI Research Press.

Lakey, B., \& Orehek, E. (2011). Relational Regulation Theory: A New Approach to Explain the Link between Perceived Social Support and Mental Health. Psychological Review, 118, 482-495. https://doi.org/10.1037/a0023477

LaRock, H. (2018). Middle Eastern Culture and Cuisine. https://traveltips.usatoday.com/middle-eastern-culture-cuisine-22651.html

Leary, M. R. (2010). Affiliation, Acceptance, and Belonging: The Pursuit of Interpersonal Connection. In S. T. Fiske, D. T. Gilbert, \& G. Lindsey (Eds.), Handbook of Social Psychology (pp. 864-897). Hoboken, NJ: Wiley. https://doi.org/10.1002/9780470561119.socpsy002024

Leary, M. R., \& Springer, C. A. (2001). Hurt Feelings: The Neglected Motion. In R. Kowalski (Ed.), Aversive Behaviors and Interpersonal Transgression (pp. 151-175). Washington DC: American Psychological Association. https://doi.org/10.1037/10365-006

Ma, G. (2015). Food, Eating Behavior, and Culture in Chinese Society. Journal of Ethnic Foods, 2, 195-199. https://doi.org/10.1016/j.jef.2015.11.004

Markus, H. R., \& Kitayama, S. (1991). Culture and the Self: Implications for Cognition, Emotion, and Motivation. Psychological Review, 98, 224-253.

https://doi.org/10.1037/0033-295X.98.2.224

Mojaverian, T., \& Kim, H. S. (2013). Interpreting a Helping Hand: Cultural Variation in the Effectiveness of Solicited and Unsolicited Social Support. Personality and Social Psychology Bulletin, 39, 88-99. https://doi.org/10.1177/0146167212465319

O'Donoghue, N. (2012). The Shape of the History of Eucharist. New Blackfrians, 93, 71-83. https://doi.org/10.1111/j.1741-2005.2011.01433.x

Ornish, D. (2007). The Spectrum. New York: Ballantine Books.

Pressman, S. D., Matthews, K. A., Cohen, S., Martire, L. M., Scheier, M., Baum, A., \& Schulz, R. (2009). Association of Enjoyable Leisure Activities with Psychological and Physical Well-Being. Psychosomatic Medicine, 71, 725-732. https://doi.org/10.1097/PSY.0b013e3181ad7978

Rokach, A. (2014). Loneliness of the Marginalized. Open Journal of Depression, 3, 147-153. https://doi.org/10.4236/ojd.2014.34018 
Rokach, A. (2017). Introduction-Intimate Relationships: What Enriches and What Depletes Them. In A. Rokach (Ed.), Marital Relationships and Parenting: Intimate Relations and Their Correlates (pp. 17-23). Abingdon: Routledge. https://doi.org/10.4324/9781315208633

Rook, D. W. (1985). The Ritual Dimension of Consumer Behavior. Journal of Consumer Research, 12, 251-264. https://doi.org/10.1086/208514

Rook, K. S., \& Charles, S. T. (2017). Close Social Ties and Health in Later Life: Strengths and Vulnerabilities. American Psychologist, 72, 567-577. https://doi.org/10.1037/amp0000104

Schug, J., Yuki, M., \& Maddux, W. (2010). Relational Mobility Explains Between- and Within-Culture Differences in Self-Disclosure to Close Friends. Psychological Science, 21, 1471-1478. https://doi.org/10.1177/0956797610382786

Tsai, J. L., Knutson, B., \& Fung, H. H. (2006). Cultural Variation in Affect Valuation. Journal of Personality and Social Psychology, 90, 288-307. https://doi.org/10.1037/0022-3514.90.2.288

Visser, M. (1991). The Rituals of Dinner. New York: Grove Weidenfeld.

Weil, A. (1997). Eight Weeks to Optimum Health: A Proven Program for Taking Full Advantage of Your Body's Natural Healing Power. New York: Knopf. 